\title{
„TEOLOGIA PRZEPIĘKNEJ I ŁASKAMI SŁYNĄCEJ STATUY MATKI NAJŚWIĘTSZEJ SEJNEŃSKIEJ". DZIEŁO SZTUKI JAKO OBIEKT KULTU I DUSZPASTERSKIE WYZWANIE
}

Wśród wielu spektakularnych inicjatyw duszpasterskich prymasa Stefana Wyszyńskiego ważne miejsce zajmowały obrzędy koronacji papieskimi koronami maryjnych wizerunków kultowych. O skali przedsięwzięcia świadczy czterdzieści siedem koronacji przeprowadzonych na terenie całej Polski. Pierwsza uroczystość miała miejsce wkrótce po objęciu biskupstwa lubelskiego, 7 lipca 1946 r. (ikona Matki Bożej z katedry na Górze Chełmskiej), ostatnia zaś odbyła się 18 sierpnia 1980 r. w sanktuarium w Wambierzycach (Kupiszewska 9-68) ${ }^{1}$.

Działalność ta z jednej strony wpisywała się w długą i bardzo nośną tradycję duszpasterską, zapoczątkowaną koronacją wizerunku Matki Bożej Częstochowskiej 8 września 1717 r. (Baranowski passim)², z drugiej - doskonale uwidoczniała szczególny rys duchowości Prymasa, który do oficjalnej dewizy biskupiej Soli Deo nieformalnie dodał per Mariam i był głęboko przekonany, że ,jeżeli Kościół nie będzie maryjny, to nie będzie katolicki, bo po cóż by Pan Bóg zaczynał od Maryi i Nazaretu?" (Romaniuk 351)33. Niemal w komplecie zachowały się teksty homilii koronacyjnych, wygłoszonych przez Prymasa w trakcie wspomnianych uroczystości ${ }^{4}$. Przedmiotem

Dr hab. Aneta Kramiszewska - Katolicki Uniwersytet Lubelski Jana Pawła II, Wydział Nauk Humanistycznych, Instytut Nauk O Sztuce, Katedra Badań nad Sztuką od Starożytności do Współczesności; e-mail: kramiszewska@kul.pl; ORCID: https://orcid.org/0000-0002-0662-5373.

${ }^{1}$ Szerzej o zjawisku współczesnych koronacji zob. Staniek, „Fenomen” 233-251.

${ }^{2}$ Do 1946 r. dokonano sześćdziesięciu jeden koronacji - zob. Witkowska 34-35.

${ }^{3}$ Por. Wyszyński, Wszystko. Szerzej zagadnienia te omawiają: Siudy 77-90; Jabłoński 37-97.

${ }^{4}$ Brakuje jedynie dwóch kazań na koronacje - w Markowicach i w Chełmie. Obszerne fragmenty wszystkich zachowanych homilii zob. Królowa Polski 69-337. W całości udostępnione są w dziale „Koronacje” na stronie internetowej Instytutu Prymasowskiego Stefana kardynała 
poniższych rozważań będzie wybrany $\mathrm{z}$ tego zasobu tekst homilii wygłoszonej 7 września 1975 r. w czasie koronacji figury Matki Bożej (w typie Madonny szafkowej) w sanktuarium w Sejnach ${ }^{5}$.

Wśród ukoronowanych przez prymasa Wyszyńskiego obiektów kultowych najwięcej jest przedstawień w typie Hodegetrii i jego wariantów (jak Matka Boża Śnieżna, Hodegetria Krakowska) oraz nieskomplikowanych ikonograficznie rzeźbionych, całopostaciowych figur Matki Bożej z Dzieciątkiem. Można wymienić także kilka wizerunków o ikonografii bardzo popularnej, niebudzącej kontrowersji, choć wśród obiektów kultowych spotykanej rzadko: sceny ukazujące Świętą Rodzinę (Matka Boża Dzikowska z Tarnobrzega; Matka Boża Świętorodzinna ze Studzianny ${ }^{6}$ ); wizerunek Piety (Bolesna Patronka Ziemi Dobrzyńskiej w Oborach), Zaśnięcie Maryi (Matka Boża ze Starej Wsi). Wśród ukoronowanych wizerunków jest także Matka Boża Łaskawa, patronka Warszawy, ze złamanymi strzałami gniewu Bożego w dłoniach.

W homiliach rzadko znajdujemy bezpośrednie odniesienia do cech stylistyczno-ikonograficznych koronowanych dzieł sztuki. Pewnym usprawiedliwieniem tego faktu może być wspomniane wyżej zjawisko powtarzania się podobnych formuł ikonograficznych, brak spektakularnych elementów przyciągających wzrok wiernych. Gdy jednak w dziele sztuki pojawiał się element wymykający się ikonograficznym standardom, był odnotowywany. Zwykle były to pojedyncze zdania lub akapity. W tym kontekście warto zwrócić uwagę na odniesienia do malutkiej, artystycznie wyjątkowo nieporadnej, figurki Matki Bożej z Wambierzyc:

Dziecię z gołąbkiem i Matka z owocem symbolizują głębokie teologiczne przemyślenie. Dziecię Jezus jest z woli Ojca dziełem Ducha Świętego, dlatego piastuje w swoich rączkach symbol Ducha, który sprawił, że Słowo Ciałem się stało pod sercem Maryi. [...] Matka Jezusa w owocu, który trzyma w swoim ręku, niejako nam przypomina, iż ona karmi swego Syna. (Królowa Polski 335)

Podobnie odnotowane w homilii zostały złamane strzały w dłoniach Maryi w obrazie patronki Warszawy, a w obrazie z Wielunia kaznodzieja odwołał

Wyszyńskiego: wyszynski prymas.pl/koronacje-obrazow-rzezb/, dostęp 5.05.2021. Teksty kazań koronacyjnych nie cieszą się popularnością badaczy, jako szerszy problem badawczy analizowali je Krzysztof Staniek (Teologia passim; „Przegląd” 247-316) i Stanisław Konik (passim).

${ }^{5}$ Mszy koronacyjnej przewodniczył kardynał Karol Wojtyła, a kazanie do tysięcy zgromadzonych pielgrzymów wygłosił koronator wizerunku - Prymas Wyszyński.

${ }^{6}$ Kazanie koronacyjne było w całości poświęcone rodzinie polskiej i katolickiej, tematycznie nawiązywało do idei Świętej Rodziny, ale nie odnosiło się bezpośrednio do malarskich komponentów obrazu. 
się do umieszczonej na płótnie inskrypcji: Monstra te esse Matrem. Są to sporadyczne przywołania, przyciągające uwagę słuchacza do obrazu, ale nie determinujące treści kazania. Oryginalnym wizerunkiem, na tle pozostałych ukoronowanych, było przedstawienie Matki Bożej z Lichenia, ukazanej w popiersiu, bez Dzieciątka, z polskim orłem na piersiach. Prymas w homilii bezpośrednio nawiązał do tej ikonografii, wykazując, że dobro narodu trzeba widzieć w Matce Boga: „Znak naszej Ojczyzny był bezpieczny na piersiach, które karmiły świata Zbawienie!" (Królowa Polski 175).

$\mathrm{Na}$ tym tle kazanie koronacyjne w Sejnach jawi się jako całkowicie oryginalne i wymykające się schematom, ponieważ zostało ściśle powiązane ze strukturą i ikonografią koronowanego dzieła sztuki. Jego wyjątkowość najlepiej ujmują słowa samego Prymasa. Cztery lata po uroczystości koronacyjnej Wyszyński odwiedził sejneńskie sanktuarium jako prywatny pielgrzym (28 lipca 1979 r.). Wygłosił wówczas słowo do zgromadzonych pątników, w którym przypomniał swoją poprzednią wizytę oraz odwołał się do wygłoszonego wówczas kazania:

Gdy byłem na koronacji tej wymownej figury Matki Bożej, wyłożyłem całą teologię przepięknej i łaskami słynącej statuy Matki Najświętszej Sejneńskiej, w której widzę symbol tajemnicy Maryi jako „prototypu Kościoła”, o której mówił Sobór Watykański II. I dlatego też moje kazanie wtedy, przed kilku laty, poświęciłem wyjaśnieniu teologicznego znaczenia tej właśnie figury Matki Najświętszej, Pani łaskawej od Trójcy Świętej, czczonej w Sejnach. („Znak wierności Trójcy Świętej” 201-202)

Intencje Prymasa zostały jasno określone: chciał objaśnić formę i ikonografię średniowiecznego wizerunku kultowego w duchu teologicznego wykładu posoborowej mariologii. Wyszyński, stając przed figurą Matki Bożej Sejneńskiej, miał pełną świadomość wyjątkowości obiektu kultowego i dał temu wyraz w kazaniu koronacyjnym: „W swoim życiu biskupim koronowałem czterdzieści kilka obrazów łaskami słynących, ale pierwszy raz staję przed postacią, która mieści w sobie tajemnicę". A nieco dalej stwierdzał: „Oto jest tajemnica, z którą się w tak realnej postaci rzeźby czy malarstwa często nie spotykamy, bo takich figur jest zaledwie kilka" (Królowa Polski 314).

Przedmiotem podziwu Prymasa Tysiąclecia była figura Matki Bożej z Dzieciątkiem, przez historyków sztuki zaliczana do typu ikonograficznego tzw. Madonn szafkowych (fr. Vierge ouvrante, hiszp. Virgen abridera, niem. Schreinmadonna; ang. Shrine Madonna) (Baumer 237-272; Kroos 58-64; 
Radler 241-274; Gonzáles Hernando passim; Katz 37-91). Rzeźba sejneńska została wykonana $\mathrm{z}$ drewna lipowego, polichromowanego i złoconego, mierzy około $112 \mathrm{~cm}$ bez korony, datowano ją na ok. 1400 r. Figura Maryi otwiera się na kształt tryptyku, skrzydła (poły jej płaszcza) umieszczono na zawiasach; we wnętrzu figury umieszczono pełnoplastyczną grupę Trójcy Świętej: Bóg Ojciec prezentuje rozpięte na krzyżu ciało martwego Jezusa, a ponad Jego głową umieszczono gołębicę Ducha Świętego. Pod względem ikonograficznym jest to kompilacja trzech samodzielnie funkcjonujących tematów: figury Maryi z Dzieciątkiem zasiadającej na tronie w ujęciu frontalnym, przedstawienia Tronu Łaski oraz Matki Bożej Płaszcza Opieki, wzbogacone o motyw księżyca z maską lunarną pod stopami Maryi. Na jej współczesny wygląd wpłynęły nowożytne uzupełnienia oraz dwie gruntowne konserwacje przeprowadzone $\mathrm{w} X X$ wieku $^{7}$. W literaturze naukowej obiekt jest znany i nieodmien-nie przywoływany w kontekście rozważań nad sztuką zakonu krzyżackiego, rzeźby gotyckiej, duchowości epoki średniowiecza oraz łączony ideowo i formalnie $\mathrm{z}$ grupą innych pomorskich rzeźb: z Klonówki, z Lubiszewa Tczewskiego i z Elbląga oraz figurami obecnie przechowywanymi w Musée de Cluny i w Germanisches Nationalmuseum w Norymberdze (Ciecholewski, „Problematyka” 127-152; Ciecholewski, „Treści” 251-288; Nowiński 120-130; Bławat 121-129). Rzeźbie sejneńskiej poświęcono kilka tekstów monograficznych, ale akcentowano w nich głównie aspekty historyczne oraz dewocyjne, jej dzieje przedstawiano jako element opowieści o sanktuarium maryjnym w Sejnach (Złotkowski passim; Kłapkowski 84-88; Jemielity, „Figura" 83-87; Boguszewska i Kistelska-Borkowska 10-13) ${ }^{8}$, z opracowań historyków sztuki przywołać można artykuł Tadeusza Jurkowlańca (65-72), który jako jedyny poświęcił uwagę nowożytnym dziejom zabytku.

Maryja skrywająca w swoim wnętrzu Trójcę Świętą była dużym wyzwaniem dla tradycyjnie rozumianych formuł ikonografii chrześcijańskiej.

\footnotetext{
${ }^{7}$ Figura została poddana „konserwacji” pod koniec XVI wieku, z tego czasu pochodzi krzyż Chrystusa. Gruntowną konserwację przeprowadzono po raz pierwszy na przełomie 1930 i $1931 \mathrm{r}$. w Warszawie. Kolejnej konserwacji poddano rzeźbę w 1967 r. w Pracowni Malarstwa warszawskiego oddziału PKZ pod kierunkiem Stanisławy Majewskiej. Zob. Jurkowlaniec 67. Ostatnie prace konserwacyjne przeprowadziła Grażyna Szumska w 1999 r.

${ }^{8}$ Być może pierwszą monografię zabytku sporządził ks. Stanisław Jamiołkowski, od 1864 do 1873 r. profesor w sejneńskim seminarium diecezjalnym oraz wicekustosz katedry. Jak wskazują jego biografowie, był autorem „broszury o figurze szafkowej Matki Boskiej Sejneńskiej”, ale jej tekst nie zachował się. Sejny uwzględnił w swoim katalogu miejsc świętych Alojzy Fridrich (430434). Ważne publikacje ukazały się tuż przed II wojną światową, niejako w ostatniej chwili dokumentując odchodzący świat (Złotkowski; Kłapkowski). Współcześnie istnienie figury odnotowują przede wszystkim publikacje o charakterze dewocyjnym i przewodniki turystyczne.
} 
Zgodnie krytykowano te wizerunki, poczynając od Jana Gersona aż po papieża Benedykta XIV, za narzucającą się wiernym sugestię „quasi vero tota Trinitas humanam carnem ex Virgine assumpsisset" (list Benedykta XIV Sollicitudini nostrae, 27, 1745 r.), tzn. że ,jakoby zaiste cała Trójca [Święta] ciało ludzkie z Dziewicy wzięła". Przedstawienia Madonn szafkowych, uchwytne w sztuce europejskiej od początku XIII do XVI wieku (gdy weszły w fazę schyłkową i odnotowujemy jedynie pojedyncze przykłady), należą do sztuki średniowiecznej i całkowicie zanikły w ikonografii potrydenckiej. Paradoks figury sejneńskiej polega na tym, że otrzymała ona szansę na „drugie życie” w sferze kultu dokładnie w tym czasie, gdy definitywnie przeminęła epoka, która ją stworzyła. Nie udało się wskazać konkretnego miejsca jej pochodzenia ani pierwotnych okoliczności kultu. Ze względu na figury krzyżackich rycerzy namalowanych na skrzydłach sugerowano, że była przeznaczona dla zakonnej kaplicy zamkowej, ale pozostaje nieuchwytna źródłowo aż do początków XVII wieku.

„Drugie życie” figury Matki Bożej rozpoczęło się oficjalnie 16 maja 1602 r., gdy Jerzy Grodziński z żoną Justyną ufundowali w rodzinnych dobrach konwent dominikanów, przekazując im ziemie kupione uprzednio od Sapiehów (Jemielity, Zespót passim; Baranowski 39-48). Ofiarował im także średniowieczną figurę maryjną, którą - jak chce tradycja - z jego inicjatywy zakupiono w Królewcu. Zakonnicy przybyli z Wilna, wraz z fundacją objęli także nowo utworzoną parafię, co nałożyło na nich obowiązki duszpasterskie. Pierwszym miejscem kultu był niewielki drewniany kościół św. Jerzego (rozebrany w 1842 r.), następnie zakonnicy ukończyli w 1619 r. budowę kościoła murowanego (konsekrowany w 1632 r.), do którego uroczyście przeniesiono figurę, umieszczając ją w ołtarzu głównym, w taki sposób, aby możliwe było jej otwarcie, w dekorowanej wnęce zwieńczonej baldachimem z kosztownymi wisiorami (Guzewicz 88). Pomimo kontrowersyjnej ikonografii kult szybko się rozwijał. Na pewno sprzyjał mu ideowy kontekst dzieła „uratowanego" z rąk protestantów, wykupionego i zabezpieczonego w nowym miejscu przed tułaczką. Można spekulować, że istniała także świadomość „starożytności” rzeźby, znacząco odbiegającej formą od ówczesnych dzieł sztuki, a owa dawność wizerunku była postrzegana pozytywnie, w kategoriach uwierzytelniających sacrum przedmiotu. Czynnikiem, który mógł wpłynąć na akceptację wizerunku, są dzieje innej figury Matki Bożej szafkowej, znajdującej się w Elblągu. Tę średniowieczną rzeźbę, pochodzącą być może z krzyżackiej kaplicy zamkowej, także umieszczono wtórnie w retabulum ołtarza głównego kościoła mariackiego (ok. 1514 r.). 
Wszystko wskazuje, że nastawę wykonano z myślą o umieszczeniu w niej kilkadziesiąt lat starszej rzeźby Madonny szafkowej i dostosowano do ekspozycji przewidującej możliwość jej otwarcia (Woziński 20-22, il. 18). Do 1542 r. kościołem opiekowali się dominikanie, pod naporem ruchu reformacyjnego rada miejska oddała kościół ewangelikom, elbląska Madonna szafkowa zniknęła jednak z miasta dopiero w 1944 r. ${ }^{9}$ Choć nie miała statusu figury kultowej, pouczające jest zauważenie, z jaką starannością zadbano o „starożytne” dzieło sztuki i artystycznie je wyeksponowano.

Zyskawszy energicznych promotorów, kult Matki Bożej Sejneńskiej musiał się szybko upowszechnić, o czym świadczy książka jezuity Jana Drewsa Methodus peregrinationis menstruae Marianae ad imaginem Deiparae Virginis per ditiones Regni Poloniae et M. Ducatus Lituaniae, wydana w Wilnie w $1684 \mathrm{r}$. Ten swoisty przewodnik dla pielgrzymów jest dla nas bardzo cenny, ponieważ zawiera także podobizny wizerunków kultowych. W pierwszej części znajdują się modlitewne rozważania podzielone na dwanaście miesięcy, w każdym miesiącu czytelnik „odwiedza” jedno sanktuarium. Jako ostatnie, dedykowane dla grudnia, umieszczono miejsce święte w Sejnach ${ }^{10}$. Nawiedzając figurę Najświętszej Maryi Panny, należy, według jezuity, wyrazić akt wiary. Serce pielgrzyma, ożywione afektami, przez stateczną i nieomylną wiarę, z własnego przekonania, pod wpływem argumentów i objaśnień, wyznaje wiarę $\mathrm{w}$ nienaruszone dziewictwo Maryi, wybranej przed wiekami na Matkę Syna Bożego, który równy jest w boskiej naturze Ojcu, będąc zarazem człowiekiem. W akcie wiary podkreślono także rolę Ducha Świętego, sprawcy poczęcia Maryi. Z taką samą niewzruszoną statecznością wyznaje się wiarę w Niepokalane Poczęcie. Następnie pielgrzym zwraca się do Maryi jako miłosiernej orędowniczki (Drews 54-56). Ten krótki tekst jest najstarszym śladem kultowej tradycji wizerunku sejneńskiego. Znamienne, że przywołano w jego kontekście Wcielenie (poprzez bezpośrednie nawiązanie do Zwiastowania) oraz Trójcę Świętą w relacji do Maryi - wybrana przez Ojca daje ludzkie ciało Synowi za sprawą Ducha, a także podkreślono miłosierdzie Matki. To wskazuje, jakie wątki ideowe łączono z otwieraną figurą w XVII wieku.

Tekstowi towarzyszy rycina, słaba artystycznie, ale w aspekcie ikonograficznym bardzo interesująca (il. 1). Rytownik dokonał pewnych korekt,

\footnotetext{
${ }^{9}$ Ewakuowana i ukryta w Turyngii, ostatecznie odnalazła się w kościele parafialnym w Vacha, a następnie przeniesiono ją do Ostpreußischen Landesmuseum w Lüneburgu.

${ }^{10}$ Madonna szafkowa znalazła się w godnym towarzystwie, Drews wymienia także wizerunki z Jasnej Góry (Madonna Częstochowska rozpoczyna peregrynację w styczniu), Żyrowic, Świętej Lipki, Trok, Wilna, Studzianny, Łąk.
} 
a ich analiza prowadzi do ciekawych wniosków. Wizerunek zaprezentowany czytelnikom jest niewątpliwie inspirowany średniowieczną rzeźbą, ale jej nie odwzorowuje. Dostrzegamy znajome elementy: Maryję, Trójcę Świętą w typie Tronu Łaski, ale jednocześnie pozbawiono figurę jej cech konstytutywnych. To już nie jest Madonna szafkowa, ponieważ zabrakło owej „szafki”, czyli otwieranych skrzydeł, przypominających konstrukcję tryptyku, zabrakło także Dzieciątka na ręku Matki. W zamian postać Maryi, także jej głowę, otacza płaszcz, podtrzymywany szeroko rozpostartymi rękami. Okazałe nakrycie jest ozdobione na zewnątrz kokardami i podbite licznymi gronostajowymi ogonkami. Na ich tle widnieją po obu stronach Maryi zarysy klęczących postaci, najwyraźniej inspirowanych figurami na skrzydłach kultowej rzeźby. Pod nogami Maryi widnieje postument z wizerunkiem Orła i Pogoni, w pionowych podziałach luźno nawiązujący do pierwowzoru, a na postumencie wspiera się Trójca Święta. Poniżej umieszczono jeszcze maskę lunarną odwróconą w stosunku do pierwowzoru. Analiza ryciny prowadzi do wniosku, że wizerunek traci swoją niepokojącą odmienność formalną i upodabnia się do niezwykle popularnych w sztuce barokowej przedstawień Maryi Płaszcza Opieki. Umieszczenie maski lunarnej (widocznej tylko wtedy, gdy figura jest zamknięta) to kolejny krok prowadzący do niwelowania odmienności, „uzgadniania” przedstawienia z wrażliwością współczesnego rytownikowi odbiorcy. Ingerencja w pierwowzór jest formalnie znacząca, ale jednocześnie przekształcenie wizerunku w Płaszcz Opieki jest zgodne $\mathrm{z}$ intencją średniowiecznego artysty, który umieścił adorantów na skrzydłach rzeźby. Wydaje się jednak, że jest to także wyraz niepokoju, jaki budzi wizerunek w praktyce duszpasterskiej. Kolportowanie go w formie ikonograficznej powszechnie zrozumiałej, budzącej skojarzenia $\mathrm{z}$ innymi podobnymi przedstawieniami, czyni przekaz bardziej jednoznacznym, zakorzenionym w tradycji. Pozwala też uniknąć ewentualnego zarzutu o propagowanie trynitarnej herezji.

$\mathrm{Z}$ epoki staropolskiej mamy drugie świadectwo kultu zapisane przez dominikanina Grzegorza Szymaka w 1755 r. (Szymak 500). W obszernym dziele sławiącym zakon kaznodziejski wspomniano także miejsca święte będące pod jego opieką, są wśród nich również Sejny. A w nich:

[...] statua misternego rznięcia z iednego drzewa lipowego, prawie trzyłokciowa, w Paludamencie adornowanym złotem malarskim, na krzesełku tegoż iednego drzewa, w lewey doyrzałe czerwone jabłko, na prawicy maluczkiego Syna P. Jezusa reprezentująca. Lubo po sprawioney R. 1720 srebrney sukience w złote kwiaty, Augszpurską robotą zda się teraz być stojąca. Niewypowiedzianey jest 
piękności, piękności barzo misternego rznięcia. Twarz nayślicznieysza, poważnie uśmiechaiąca się, y patrzących czystego sumienia do nabożeństwa pobudzająca, grzesznych strachem przeymuiąca, iagody obu osóbek ni krew z mlekiem zmieszana wydaią się. Statua ta od szyi; z pod pereł, korali, kanaków y inszych dość bogatych kleynotów, otwiera się na zawiaskach żelaznych aż do dołu, na dwoye: y inną daleką misternieyszą wewnątrz reprezentuje figurę. Bo rękoma na krzyż rozciągnionemi rozpostartym, okrywa płaszczem klęczące, z złożonemi do modlitwy rękami, Krzyżaki, y inne rożnych stanow y eminencji, oboiey płci osoby, u nog swych, barzo staroświekim stroiem. W samych otwartey statuy wnętrznościach, iest wyobrażenie niejakie Tróycy SS. Bog Oyciec, w rozciągnionych ręku trzyma na Krzyżu przybitego Syna. Nad niemi Duch SS. w postaci gołębicy. Wszystko to jest rznięto z tegoż iednego drzewa, ale farbami barzo przypadłemi, do rożnych szat twarzy, iest adoptowane, piękne do zadumania. (Szymak 500)

Ojciec Szymak odnotował także brak wiadomości o pochodzeniu rzeźby, ale podkreślił, że wyrzucono ją z jakiegoś kościoła ,z nastaniem nowych Obrazoborcow Lutrow, y Kalwinow, którzy przedawali Polakom co piękniejsze obrazy, a inne palili" (500).

Intuicja, którą odczytywaliśmy z siedemnastowiecznej ryciny, potwierdza się w tekście Szymaka. Pisze on o figurze w „paludamencie adornowanym”, czyli w ozdobnym płaszczu, i ponownie o tym, że Maryja „okrywa płaszczem” klęczące postacie. Jednocześnie ściśle technicznie tłumaczy, że figura otwiera się na żelaznych zawiaskach. Wynika z tego zestawienia, że forma i treść zostały rozgraniczone, każda z nich postrzegana jest niejako osobno. Ekstrawagancka konstrukcja rzeźby została po prostu przetłumaczona w duchu tradycyjnej ikonografii, oto mamy coś na kształt płaszcza na zawiaskach. O żywym kulcie świadczą ozdoby rzeźby, która obwieszona jest rozmaitą biżuterią i ma drogocenną sukienkę ,augsburskiej” roboty ${ }^{11}$. Dominikanin dostrzega dysonans, który stąd wynika. Sukienka szczelnie okrywająca korpus rzeźby zwodzi patrzącego co do formy samej rzeźby. W tym nowym ubiorze figura Madonny szafkowej właściwie znika sprzed oczu wiernych

${ }^{11}$ Dominikanie dodali także, choć trudno precyzyjnie ustalić, kiedy to się stało, drogocenny różaniec, który Maryja trzymała w lewej dłoni. Znak szeroko propagowanej przez zakon modlitwy różańcowej bezpośrednio wiązał figurę $\mathrm{z}$ aktualnymi ówcześnie formami kultu (w sanktuarium jednym z dni odpustowych było święto Matki Bożej Różańcowej) i był kolejnym elementem dostosowującym pierwotną ikonografię do nowożytnych potrzeb duszpasterskich. Wspomnieć należy również o dodatkowych elementach od XVII wieku dekorujących otoczenie figury, czyli srebrnych płaskorzeźbach sześciu aniołków, z których jedna para podtrzymywała koronę Matki Boskiej, druga - baldachim, trzecia zaś para klęczących ze świecami aniołków była ustawiona u podstawy figury. Korony zostały nałożone na głowę Maryi i Dzieciątka wraz z przeniesieniem figury do nowego murowanego kościoła wybudowanego przez dominikanów, nie były to korony papieskie, a figura nie miała statusu oficjalnie koronowanego wizerunku. 
(i1. 2-3 $)^{12}$. Choć praktyka okrywania wizerunków kultowych metalowymi sukienkami była w Rzeczypospolitej powszechna i nie budziła kontrowersji, to $\mathrm{w}$ tym przypadku można stwierdzić, że przyczyniła się ona na dziesiątki lat do praktycznego usunięcia sprzed oczu wiernych wizerunku kultowego w takiej postaci, w jakiej się przedstawiał w rzeczywistości. I trudno nie zauważyć, że był to czynnik sprzyjający opiekunom sanktuarium. Przytoczone teksty dają pewien wgląd w sposób, w jaki poradzono sobie wkulcie z kontrowersyjną ikonografią. Nie wydaje się, aby wykorzystywano bogactwo ideowe zawarte w tym wizerunku, aby budowano wokół treści rzeźby pogłębiony przekaz duszpasterski dla masowego odbiorcy. Pośrednio mogą o tym świadczyć odpusty, które uroczyście sprawowano w święto patronalne kościoła (Nawiedzenia NMP, 2 lipca), w święto Matki Bożej Różańcowej (7 października) oraz w święto Matki Bożej Szkaplerznej (16 lipca). Świadczą one o propagowaniu różnorodnych aspektów kultu maryjnego, ale w żaden sposób nie uwidacznia się w nich wyjątkowość obiektu kultowego ${ }^{13}$.

W 1804 r. dokonano kasaty klasztoru dominikanów, w 1818 r. utworzono diecezję sejneńską, czyli augustowską, a kościół podominikański stał się jej katedrą. Utworzona przy katedrze kapituła w 1832 r. podjęła decyzję, aby figura Matki Bożej nigdy nie była otwierana w przyszłości (Jurkowlaniec 66). Nie znamy uzasadnienia tej decyzji. Mogła być spowodowana stanem figury, jak spekulują badacze, ale mogła także być wyrazem niezgody na propagowanie wyobrażenia niosącego ryzyko niewłaściwego odczytania. Cokolwiek tę decyzję motywowało, jej efekt był jednoznaczny zatrzaśnięto rzeźbę, odcinając wiernych od bogactwa jej treści. W $1866 \mathrm{r}$. odrestaurowano figurę, prawdopodobnie nie zdejmując $\mathrm{w}$ ogóle sukienki. Wiek XIX przyniósł także zmiany w ekspozycji rzeźby. W 1882 r. przeniesiono ją z ołtarza głównego do nowo wybudowanej przez biskupa Piotra Wierzbowskiego kaplicy bocznej kościoła i umieszczono w ołtarzu, gdzie znajduje się do dzisiaj ${ }^{14}$. W 1926 r., gdy utworzono diecezję łomżyńską i włączono do niej Sejny, przy kościele powstała kapituła kolegiacka. Zdecydowała ona o gruntownej konserwacji figury Matki Bożej, wraz ze

${ }^{12}$ Sukienkę ufundował przeor konwentu Franciszek Kosiewski, została zdjęta z figury dopiero w trakcie konserwacji na przełomie 1930 i 1931 r., obecnie jest eksponowana w gablocie w kaplicy Matki Bożej Sejneńskiej wraz z wotami.

${ }^{13}$ Szerzej o działalności duszpasterskiej dominikanów w tym czasie zob. Miławicki 105-106.

${ }^{14}$ Formalnie była to druga translacja figury. Kościół sejneński został gruntownie przebudowany i powiększony w $1760 \mathrm{r}$. Zmieniono wówczas jego orientację, zburzono chór zakonny i prezbiterium, dobudowano w ich miejsce dwa dodatkowe przęsła nawy i nową fasadę od strony miasta, ale figurę Matki Bożej nieodmiennie ustawiono w nowym ołtarzu głównym kościoła. 
zdjęciem metalowych sukienek ${ }^{15}$. W 1931 r., w czasie święta patronalnego we wspomnienie Nawiedzenia NMP, po raz pierwszy pokazano odnowioną i otwartą rzeźbę wiernym. Zyskała popularność, o czym może świadczyć fotografia zamkniętej i otwartej figury umieszczona w przewodniku Grodno i okolice - Jeziora Augustowskie, Suwalszczyzna, wydanym w Grodnie 1934 r., opatrzona dość bałamutnym podpisem Tryptyk z pocz. XVI w. w kościele podominikańskim.

Prześledzenie w zarysie dziejów kultu figury sejneńskiej pozwala ukazać pełny kontekst nauczania prymasa Wyszyńskiego i niezwykłość koronacyjnego kazania. Można powiedzieć, że tak jak figura Maryi otwiera się na wiernych, tak Prymas Wyszyński otworzył nauczanie Kościoła na rzeźbę Maryi. Po raz pierwszy w historii kultu wykorzystano w pełni ideowy potencjał tkwiący w średniowiecznej rzeźbie, a to, co onegdaj niepokoiło i uwierało $\mathrm{w}$ jej ikonografii, zostało zauważone i wykorzystane. Potencjał tego dzieła sztuki mógł dostrzec tylko człowiek, który w kazaniu wygłoszonym na Jasnej Górze do duszpasterzy sanktuariów maryjnych (1959) stwierdzał: „Kościół jest maryjny, bo cała Trójca Święta jest maryjna” (Wyszyński, Gtos 102).

Kazanie koronacyjne ma wydźwięk trynitarny i w całości służy przekazaniu wiernym prawdy o działaniu Trójcy Świętej w życiu Kościoła (il. 3-6). Rozpoczyna się, w nawiązaniu do Liturgii Słowa, obrazem Wieczernika, Maryi i Apostołów oczekujący na Zesłanie Ducha Świętego. Wieczernikiem koronacyjnym zostaje nazwana wspólnota wiernych na czele z Prymasem i kapłanami, oczekująca na nałożenie koron na łaskami słynącą figurę. Tajemnicę Wieczernika Prymas próbuje objaśnić wiernym, wracając do momentu Zwiastowania i przywołując ten najważniejszy dialog, zakończony pokornym fiat Maryi.

W ten sposób wokół Dziewczęcia, zwanego imieniem Maryi, skupiła się cała Trójca Święta: Bóg Ojciec, który posyła Zwiastuna, aby objawił zadanie, wyznaczone Jej przez Boga; czekający na odpowiedź Dziewczęcia Syn Boży, który posłuszny Ojcu, na przyzwolenie Maryi przychodzi, i Duch Święty, który roz-

${ }^{15}$ Szczegółowy opis konserwacji z punktu widzenia dzisiejszych standardów raczej mrozi krew w żyłach: ,zdjęto ostrożnie pokłady farb i złocenia, potem zaprawę gipsową, jako podkład mocno spękany i odpadający. Znaleziono pod nim warstwę płótna naklejonego na drzewo [...]”, którą także usunięto, pozostawiając jedynie oczyszczone ze wszystkich warstw drewno. „Poflekowano dziury i szczerby od gwoździ, uzupełniono brakujące szczegóły i całą figurę po odpowiednim nagrzaniu nasączono warstwę wierzchnią rozgotowanym ukropem zaprawionego kleju stolarskiego, który po stwardnieniu wypolerowano. [...] Złocenie wykonał p. [Franciszek] Sidorowicz złotem dukatowym, a pan prof. M. Gryczyński pomalował na nowo farbami olejnymi”. Zob. Złotkowski 86-87. 
poczyna swoje subtelne, delikatne działanie, kształtując pod Sercem Maryi ciało Słowu Przedwiecznemu. Maryja pierwsza w znanych nam dziejach Objawienia, skupiła przy sobie działanie całej Trójcy Świętej. Misterium Maryi to misterium pierwszego spotkania się człowieka w sposób tak wyrazisty z całą Trójcą Świętą ${ }^{16}$.

Kolejny fragment jest poświęcony przypomnieniu formuły trynitarnej zawartej w Ewangelii według św. Mateusza. Jezus dokonuje rozesłania Apostołów na misje, aby nauczali w imię Ojca i Syna, i Ducha Świętego. Prymas zauważa, że właśnie na tym polega odrębność Kościoła Chrystusowego - na działaniu na człowieka w imię Trójcy Świętej, i przypomina, że w każdej parafii do dziś kapłani chrzczą nowo narodzone dzieci w imię Ojca i Syna, i Ducha Świętego. To działanie odtwarza i uzmysławia działanie Trójcy Świętej w Nazarecie. Kaznodzieja podkreśla, że „wszystkie niemal działania Kościoła Chrystusowego są działaniami mocą Trójcy Świętej”. Wierni noszą w sobie Boga, a ich ciała są Jego świątynią.

$\mathrm{Na}$ wzór działania w Maryi, w każdym człowieku mieszka ukryty Bóg, każdy ma swoją tajemnicę, analogicznie jak Matka Boża. Wierni - ogarnięci mocami stwórczymi Ojca, który pierwszy umiłował, mocami Chrystusa, który żyje w Kościele, i Ducha Świętego, którego miłość Boża rozlana jest w sercach - są nieustannie zespoleni z Trójcą Świętą.

W kontekście tej powszechnej tajemnicy Prymas odsłania tajemnicę rzeźby sejneńskiej:

Gdybyśmy odsłonili wnętrze tej figurki, co byśmy dostrzegli? Odtworzony obraz Ojca, Ukrzyżowanego Syna i Ducha Świętego. (...) Tkwi w tym głęboka prawda teologiczna, której wyrazistość widzimy w Zwiastowaniu w Nazaret. Można tego należycie nie rozumieć, ale wolno człowiekowi próbować odsłonić tajemnicę Boga ukrytego w życiu Maryi, tajemnicę, którą nosiła Ona w sobie od Zwiastowania, w którym działał Bóg Ojciec, Bóg Syn i Bóg Duch. Wkrótce ujawniła się coś więcej: oto Maryja zrozumiała, że przez Bożego Syna miecz boleści przeniknie wielokrotnie Jej serce, jak gdyby na Jej Sercu zostanie wyryty krzyż z Golgoty. Wasza Pani Sejneńska nosi ukrytą tajemnicę (...) tajemnicę Trójcy Świętej, w pełnym wyrazie wszystkich Jej działań - działania Stwórcy, działania Ukrzyżowanego Zbawcy i uświęcającego Ducha.

Wyszyński podkreśla, że starożytna rzeźba jest próbą odsłony wielkiej tajemnicy Maryi, ale jednocześnie jest to tajemnica każdego z nas, prototyp

\footnotetext{
${ }^{16}$ Wszystkie cytaty z kazania koronacyjnego zamieszczone w tekście artykułu zaczerpnięto z: „Maryja - ukształtowana przez Trójcę Świętą - wzorem dla nas. Koronacja Matki Bożej Sejneńskiej. [Sejny, 7 września 1975]". Instytut Prymasowski, wyszynskiprymas.pl/wp-content/ uploads/2020/10/1975-09-07-sejny.pdf, dostęp 10.05.2021.
} 
dla życia każdego człowieka. Kaznodzieja nawiązuje także do aktualnego nauczania Kościoła.

W czasie Soboru nazwano Maryję prototypem, prawzorem Kościoła. I słusznie. Bo jeżeli Trójca Święta jest szczególnym znamieniem Kościoła, a Maryja przeżyła działanie Trójcy Świętej na sobie w Nazaret, to w Kościele, w jego centrum i sercu, musi być ta, która była w Wieczerniku Zielonych Świątek, gdy Jezus od Ojca posyłał Ducha Świętego.

Prymas rekapituluje ten wątek stwierdzając: „Wy tutaj macie łaskę, że w postaci Pani Sejneńskiej odtworzony jest prototyp działania Boga na człowieka, na Maryję, która jest prawzorem Kościoła i na każdego z nas". W zakończeniu kazania rozwija wątek oddziaływania trzech Osób Boskich w duszy człowieka i przypomina, że ochrzczeni w imię Ojca i Syna, i Ducha Świętego jesteśmy dziełem Trójcy Świętej. „Trójca Święta jest nieustannie z nami i nigdy nas nie opuszcza".

Nie dziwcie się staremu rzeźbiarzowi, że swoją żywą wiarę - jak głęboko wyczutą! - wypowiedział w rzeźbie, w której wnętrzu umieścił wizerunek Ojca, Syna i Ducha. Za przykładem Maryi mamy odbijać w sobie wizerunek Ojca, Syna i Ducha, ażeby odbijało się w nas światło Oblicza Bożego, abyśmy wszyscy byli rozpromienieni jako wybrańcy Boży, święci i umiłowani, przedziwną mocą działającą w Kościele [...].

Oto jest misterium, które odsłaniamy, misterium waszej Matki Sejneńskiej, danej wam po to, abyście odtwarzali je w sobie, a patrząc na Nią - mieli w sobie Boga w Trójcy Świętej Jedynego. Nie widzicie w tej chwili znaków Trójcy Świętej [w czasie koronacji figura pozostawała zamknięta], ale gdy patrzymy wzajemnie na siebie - chociaż jesteśmy pełni Ojca, Syna i Ducha - również tego nie widzimy $[\ldots]$.

Konkluzja kazania brzmi:

Z uroczystości koronacji Matki Bożej Sejneńskiej, którą bym nazwał Matką od ukrytej w jej wnętrzu Trójcy Świętej, wrócicie, umiłowane Dzieci Boże, do swoich domów. Wrócicie świadome, że wszyscy nosicie w sercach waszych Boga w Trójcy Świętej Jedynego, chociażby ludzie tego nie widzieli, jak my tego nie widzimy w figurze, którą za chwilę będziemy koronować.

Zacznijmy od podsumowania kazania, bo to moment znamienny. Prymas Wyszyński nadał kultowej figurze nowe miano: Maryja od Trójcy Świętej. Działanie to nie jest wyjątkowe, w pięciu innych sanktuariach Prymas zapro- 
ponował nowe nazwy Maryi w Jej koronowanych wizerunkach, ale nigdzie nie były one związane z ikonografią konkretnego zabytku (Kupiszewska 62). W Sejnach pojawiło się określenie definiujące kult poprzez ikonografię i formę dzieła. Jak wskazano wyżej, głęboki sens teologiczny kazania odnosi wiernych do nauczania Kościoła o Trójcy Świętej. Trynitarne konteksty maryjne odsłaniają przed czytelnikiem różne teksty Prymasa Wyszyńskiego, w licznych wypowiedziach nie ma jednak syntetycznego wykładu na temat relacji Maryja-Trójca Święta (Pach 396). Na przykład 20 maja 1954 r. zanotował w trakcie pobytu w Stoczku Warmińskim:

Pierwszym dziełem naprawionego porządku, z woli Trójcy Świętej, jesteś Ty, Maryjo. Ojciec - Rodziciel przyzywa Cię na Matkę Synowi Jednorodzonemu. Syn wybiera sobie mieszkanie w Przybytku Twoim, Duch Święty ogarnia Cię, Oblubienico, miłością swoją. Cała Trójca Święta jest nad Tobą i w Tobie. Jesteś najdoskonalszym Dziełem Trójcy Świętej w porządku natury i łaski. (Wyszyńki, Zapiski 96-97)

Refleksję tę pogłębił w rozważaniach $\mathrm{z}$ okazji rozpoczęcia nowenny przed świętem Zwiastowania (16 marca 1956 r.):

[...] Ojciec Słowa staje się Ojcem Syna Człowieczego, Słowo Przedwieczne zespala w sobie naturę ludzką. Duch Święty jednoczy Boże z ludzkim. Maryja staje się Matką Boga, Świątynią Boga, Przybytkiem Ducha Świętego. Ogarnia Nieogarnionego, Beata viscera... (Wyszyński, Zapiski 315).

Na marginesie można zauważyć, że kazanie wygłoszone w Sejnach współbrzmi z głęboką trynitarną duchowością Prymasa Wyszyńskiego. W niezwykle ważnym dla niego akcie osobistego oddania się w niewolę Matce Najświętszej deklarował: „Wszystko, cokolwiek czynić będę, przez Twoje Ręce Niepokalane, Pośredniczko łask wszelakich, oddaję ku chwale Trójcy Świętej - Soli Deo!"17.

W kazaniu koronacyjnym Prymas sięgnął do pierwotnej idei zawartej w średniowiecznej rzeźbie, ukazując wiernym Maryję jako tabernaculum Dei et verbi. Tę trudną teologicznie prawdę uczynił bliską każdemu słuchaczowi poprzez ukazanie wspólnoty wszystkich wierzących. Maryja jest pierwszym człowiekiem w sposób doskonały noszącym w sobie Trójcę Świętą, ale każdy chrześcijanin włączony przez chrzest we wspólnotę Kościoła w sposób szczególny posiada Trójcę Świętą - nosi ją w sobie jak

${ }^{17}$ Akt oddania się w niewolę Chrystusowi przez ręce Maryi Prymas Wyszyński uczynił 8 grudnia 1953 r. w czasie uwięzienia w Stoczku Warmińskim (Wyszyński, Zapiski 58). 
tajemnicę, niczym zamknięta rzeźba Maryi osłaniająca przed wzrokiem innych Tron Łaski. Kaznodzieja nie poprzestał na tradycji, podjął także wysiłek wpisania rzeźby sejneńskiej w aktualną, posoborową mariologię. Aby zrozumieć kontekst tego nauczania, należy sięgnąć do Konstytucji dogmatycznej o Kościele Lumen gentium, której VIII rozdział jest poświęcony „Błogosławionej Maryi Dziewicy Bożej Rodzicielce w tajemnicy Chrystusa i Kościoła" (Konstytucja rozdz. VIII; Bujak 23-31). Daje on wyraz nowej refleksji mariologicznej, przed Soborem Watykańskim II głównie chrystologicznej, w przywołanym dokumencie, kładącej nacisk na eklezjologię, trynitologię i pneumatologię ${ }^{18}$. W omawianym kazaniu koronacyjnym brzmią echa nauczania Soboru:

I oto Kościół, rozważając Jej tajemniczą świętość i naśladując Jej miłość oraz spełniając wiernie wolę Ojca, dzięki przyjmowanemu z wiarą słowu Bożemu sam także staje się matką: przez przepowiadanie bowiem i chrzest rodzi do nowego i nieśmiertelnego życia synów z Ducha Świętego poczętych i z Boga zrodzonych. (LG nr 64)

W roku poprzedzającym koronację figury Matki Bożej Sejneńskiej, konkretnie 2 lutego 1974 r., papież Paweł VI ogłosił adhortację Marialis cultus, a w niej stwierdzał: „Najbardziej zwłaszcza wypada, by praktyki pobożności względem Maryi Panny wyraźnie wykazywały charakter trynitarny i chrystologiczny, jako że z samej swej natury jest on im właściwy i przynależny do ich istoty" (MC nr 25; za: Paweł VI 51). Kazanie koronacyjne wygłoszone w Sejnach jest wzorcowym wdrożeniem papieskiego programu duszpasterskiego.

Wśród badaczy zajmujących się problematyką średniowiecznych rzeźb Madonn szafkowych żywe dyskusje wzbudził problem przeznaczenia tych dzieł. Ze względu na niecodzienną strukturę wskazywano na możliwość używania ich jako nastaw ołtarzowych, ołtarzy polowych, relikwiarzy, tabernakulów, tym samym próbowano funkcjonalnie uzasadnić ruchomą konstrukcję, uznając, że stanowi klucz do zrozumienia rzeźb. Dysponenci rzeźby sejneńskiej jako wizerunku kultowego $\mathrm{w}$ zasadzie zrezygnowali $\mathrm{z}$ tego potencjału, uznając go za kłopotliwy balast. Można stwierdzić, że ideowo

${ }^{18}$ Warto także wspomnieć w tym kontekście działania Prymasa w czasie trwania Soboru. 15 września 1964 r. wraz z Episkopatem Polski złożył papieżowi Pawłowi VI Memoriat zawierający prośbę o wprowadzenie do nauczania soborowego tytułu „Matka Kościoła”, a następnego przemawiał w tej materii na sesji ogólnej Soboru. Tytuł Matki Kościoła nie znalazł się w Lumen gentium, ale został umieszczony w Wyznaniu wiary, ogłoszonym przez Pawła VI na zakończenie Roku Wiary 29 czerwca 1968 r. 
„zredukowano” ją do figury Matki Bożej z Dzieciątkiem, stawiając w rzędzie dziesiątków innych obrazów i figur o tradycyjnej ikonografii - spowita w metalową sukienkę jako taka jawiła się przed oczami wiernych, którzy przybywali do sanktuarium. Widzimy proces jej powolnego znikania, wycofywania rzeczywistego wizerunku, tworzenia jego kreacji na potrzeby kultu. Gdy odrestaurowano ją i otworzono w 1931 r., towarzyszyła temu aktowi także świadomość historycznej wartości dzieła oraz szacunku dla artystycznych i estetycznych wartości, które w sobie zawierało. Warto przypomnieć, że tuż przed konserwacją ukazał się obszerny artykuł Waltera Friesa, który dał początek badaniom nad typem ikonograficznym Madonn szafkowych, ze szczególnym uwzględnieniem rzeźb grupy pomorskiej (Fries 5-69). Badacz ten uwzględnił w swoim studium także rzeźbę z Sejn, łącząc ją z grupą rzeźb powstałych pod egidą zakonu krzyżackiego (wymienia także obiekty z Klonówki, Lubieszewa Tczewskiego, Elbląga, Cluny i Norymbergi). Odnotował jej stan jeszcze w nałożonej metalowej sukience (Fries 19-20) ${ }^{19}$. Można uznać, że rzeźba sejneńska uzyskała tym samym w odbiorze wiernych status dzieła sztuki, a nie tylko obiektu kultowego. Ta swoista „muzealizacja” nadała jej blasku (bardzo dosłownie to rozumiejąc w odniesieniu do nowo pomalowanego korpusu), upowszechniła jej pierwotny wizerunek, ale nie wniosła nowych treści do duszpasterstwa z nią związanego. Dopiero Prymas, nadając nowy kultowy tytuł figurze - „Maryja od Trójcy Świętej”, w pełni wykorzystał potencjał ikonograficzny tkwiący w średniowiecznym zabytku. W księdze pamiątkowej, umieszczonej przed kaplicą Matki Bożej, podczas wizyty 28 lipca 1979 r. zapisał między innymi: „(...) odtąd figura Matki Bożej może być otwierana w główne święta kolegiackie, parafialne i pielgrzymie, jak również ilekroć względy duszpasterskie będą tego wymagały (...)” (il. 7). Deklaracja Prymasa: „Gorąco pragnę, żeby wszyscy widzieli i rozumieli znak powiązania Matki Najświętszej z dziełem Trójcy Świętej” (Wyszyński, „Znak wierności Trójcy Świętej”) została tym samym wprowadzona w życie. Obecnie stosowaną w sanktuarium sejneńskim praktyką duszpasterską jest uroczyste otwarcie rzeźby Maryi w pierwszą niedzielę września, w rocznicę koronacji. Jest ona wówczas przenoszona $z$ kaplicy do ołtarza głównego i tam eksponowana (il. 8). Warto odnotować także, że od 1999 r. zasłonę łaskami słynącej figury stanowi współczesny obraz Matki Bożej Brzemiennej. To sięgnięcie do również średniowiecznej w swojej genezie ikonografii stanowi interesujący obrazowy dialog z teologiczną treścią kultowego wizerunku, wzmacniający jego przesłanie.

\footnotetext{
${ }^{19} \mathrm{Na}$ artykuł Friesa powoływał się w swojej monografii Kłapkowski (85).
} 
Niezwykła jest ta rewitalizacja średniowiecznej ikonografii, która zniknęła bezpowrotnie $\mathrm{z}$ warsztatów twórców sztuki sakralnej i religijnej ponad cztery wieki temu, nigdy nie należała do popularnych typów ikonograficznych, natomiast nieustannie towarzyszyły jej głosy krytyczne, zatroskane o właściwy odbiór dzieła. Kazanie koronacyjne Prymasa Stefana Wyszyńskiego, wygłoszone w duchu odnowy mariologii po Vaticanum II, wyjątkowo współbrzmiące $\mathrm{z}$ jego osobistą duchowością, w oryginalny sposób podniosło obecność kultowego wizerunku. Kaznodzieja w istocie nie objaśnił jego treści, nie wyświetlił tajemnicy figury, ale stwierdził, że każdy ochrzczony członek wspólnoty Kościoła nosi taką samą tajemnicę działania Trójcy Świętej w swoim wnętrzu. Tajemnica nadal pozostaje tajemnicą, ale dzielimy ją wespół z Maryją. Kazanie buduje wspólnotę i angażuje do tego celu konkretne formalne i ikonograficzne elementy wizerunku kultowego. Dzieje kultu sejneńskiej figury maryjnej pokazują, jakim wyzwaniem może stać się dzieło sztuki, gdy zostaje wyniesione do rangi obiektu kultowego. Prymas Wyszyński potrafił wykorzystać jego potencjał i otworzyć je na wiernych oraz współczesne duszpasterstwo ${ }^{20}$.

\section{BIBLIOGRAFIA}

Baranowski, Andrzej J. Koronacje wizerunków maryjnych w czasach baroku. Zjawisko kulturowe $i$ artystyczne. Instytut Sztuki PAN, 2003.

Baranowski, Andrzej J. „Zespół podominikański w Sejnach”. Litwa i Polska. Dziedzictwo sztuki sakralnej, red. Wojciech Boberski i Małgorzata Omilanowska, Wydawnicwto DiG, 2004, ss. 39-48.

Baumer, Christoph. „Die Schreinmadonna in geographischer und chronologischer Ordnung”. Marian Library Studies, nr 9, 1977, ss. 237-272.

Bławat, Adam. „Pomorskie Madonny szafkowe i ich rola w liturgii obozowej zakonu krzyżackiego na przełomie XIV i XV wieku”. Nie tylko broń. Niemilitarne wyposażenie wojowników w starożytności i średniowieczu, red. Witold Świętosławski, Łódzkie Towarzystwo Naukowe, 2008, ss. 121-129.

Boguszewska, Beata, i Klara Kistelska-Borkowska. Księga łask w Sanktuarium Matki Boskiej Sejneńskiej w Sejnach. Wydawnictwo JUT, 2017.

Bujak, Janusz. „Relacje Maryi do Osób Trójcy Świętej w świetle VIII rozdziału Konstytucji dogmatycznej o Kościele 'Lumen gentium'”. Colloquia Theologica Ottoniana, nr 2, 2018, ss. 23-41.

${ }^{20}$ Ks. prałatowi Zbigniewowi Bzdakowi, proboszczowi Parafii pw. Nawiedzenia Najświętszej Maryi Panny w Sejnach, dziękuję za udzielone informacje oraz udostępnienie materiałów fotograficznych, wykorzystanych w niniejszym artykule. 
Ciecholewski, Roman. „Problematyka badawcza pomorskich madonn szafkowych”. Studia Pelplińskie, t. 8, 1977, ss. 127-152.

Ciecholewski, Roman. „Treści teologiczne pomorskich Madonn szafkowych”. Studia Pelplińskie, t. 15,1984 , ss. $251-288$

Drews, Jan. Methodus peregrinationis menstruae Marianae ad imaginem Deiparae Virginis per ditiones Regni Poloniae et M. Ducatus Lituaniae. Vilnae, 1684.

Fries, Walter. „Die Schreinmadonna”. Anzeiger des germanischen Nationalmuseums, 1928/1929, ss. 5-69.

Fridrich, Alojzy. Historye cudownych obrazów Najświętszej Maryi Panny w Polsce. T. 3, Wydawnictwo Towarzystwa Jezusowego, 1908.

Gonzáles Hernando, Irene. El arte bajomedieval y Su proyección. Temas, funciones y contexto de las Virgenes abrideras triptico. Editorial Academica Espanola, 2011.

Guzewicz, Wojciech. „Sejneński ośrodek kościelny (wybrane zagadnienia)”. Civitas et Lex, nr 2 (10), 2010, ss. 87-97.

Jabłoński, Zachariasz S. „Inicjatywy maryjne Kardynała Stefana Wyszyńskiego”. Na polskiej drodze maryjnej. Materiaty z sympozjum mariologiczno-maryjnego. Pasierbiec, 21-22 października 2006 roku, red. Anna Gąsior i Janusz Królikowski, Polskie Towarzystwo Mariologiczne, 2007, ss. 37-97.

Jemielity, Witold. „Figura Matki Bożej Sejneńskiej”. Rozporządzenia Urzędowe Łomżyńskiej Kurii Diecezjalnej, nr 2-4, 1973, ss. 83-87.

Jemielity, Witold. Zespół podominikański w Sejnach. Kuria Diecezjalna w Łomży, 1989.

Jurkowlaniec, Tadeusz. „Madonna szafkowa w Sejnach”. Litwa i Polska. Dziedzictwo sztuki sakralnej, red. Wojciech Boberski i Małgorzata Omilanowska, Wydawnictwo DiG, 2004, ss. $65-72$.

Katz, Melissa R. „The non-gendered appeal of Vierge Ouvrante sculpture: audience, patronage, and purpose in medieval Iberia". Reassessing the Roles of Women as 'Makers' of Medieval Art and Architecture, red. Therese Martin, Brill, 2012, ss. 37-91.

Kłapkowski, Władysław. Konwent dominikanów w Sejnach, [s.n.], 1939.

Konik, Stanisław. Od Starej Wsi do Jazłowca. Sanktuaria maryjne $w$ dziejach Polski. Implikacje historyczno-religijne w świetle maryjnych kazań „,koronacyjnych” XIX i pierwszej połowy XX wieku, Zakład Poligraficzny SAM-WIL, 2010.

Kroos, Renate. „Gottes Tabernakel. Zu Funktion und Interpretation von Schreinmadonnen”. Zeitschrift für Schweizerische Archäologie und Kunstgeschichte, z. 1, 1986, ss. 58-64.

Królowa Polski o wielu obliczach. Wizerunki Matki Bożej koronowane przez prymasa tysiaclecia Stefana kardynała Wyszyńskiego, Instytut Prymasa Wyszyńskiego, 2014.

Konstytucja dogmatyczna o Kościele „Lumen gentium”. Wydawnictwo Wrocławskiej Księgarni Archidiecezjalnej, 1986.

Kupiszewska, Helena Teresa. „Wizerunki Matki Bożej koronowane przez Prymasa Tysiąclecia”. Królowa Polski o wielu obliczach. Wizerunki Matki Bożej koronowane przez prymasa tysiąclecia Stefana kardynała Wyszyńskiego. Instytut Prymasa Wyszyńskiego, 2014, ss. 9-68.

Miławicki, Marek. „Miejsce religijności ludowej w działalności duszpasterskiej dominikanów w Polsce północnowschodniej w okresie staropolskim”. Parafia rzymskokatolicka w Choroszczy 550 lat. Księga pamiątkowa, red. Tadeusz Kasabuła i Adam Szot, Wydawnictwo Buk, 2009, ss. 101-121. 
Nowiński, Janusz. Ars Eucharistica. Idee, miejsca i formy towarzyszace przechowywaniu eucharystii w sztuce wczesnochrześcijańskiej i średniowiecznej. Neriton, 2000.

Pach, Jan. „Komunia życia Maryi z Trójcą Świętą w nauczaniu Stefana Kardynała Wyszyńskiego". Trójca Święta a Maryja. Materiały z sympozjum mariologicznego, Częstochowa, 6-8 IX 1999 r., red. Teofil Siudy i Kazimierz Pek, Polskie Towarzystwo Mariologiczne, 2000, ss. 393-403.

Paweł VI. Jak czcić Matkę Bożą? Adhortacja apostolska papieża Pawła VI „Marialis cultus” o należytym ksztaltowaniu i rozwijaniu kultu Najświętszej Maryi Panny. Wstęp Stanisław Celestyn Napiórkowski, Wydawnictwo OO. Franciszkanów, 1984.

Radler, Gudrun. „Der Beitrag des Deutschordenslandes zur Entwicklung der Schreinmadonna (1390-1420)". Sztuka w kręgu zakonu krzyżackiego w Prusach i Inflantach, Wydawnictwo Uniwersytetu Mikołaja Kopernika, 1995, ss. 241-274.

Romaniuk, Marian P. Życie, twórczość i postuga Prymasa Tysiąclecia: 1972-1981, t. 4, IW Pax, 2002.

Siudy, Teofil. „Duchowość maryjna w życiu i nauczaniu Prymasa Tysiąclecia”. Duchowość Prymasa Tysiaclecia. Materiały z sympozjum, red. Jan Machniak i Jerzy W. Gogola, Wydawnictwo Karmelitów Bosych, 2002, ss. 77-90.

Staniek, Krzysztof. „Fenomen sanktuariów maryjnych z koronowanymi obrazami i figurami Matki Bożej w Polsce w II połowie XX wieku”. Salvatoris Mater, t. 5, nr 1, 2003, ss. 233-251.

Staniek, Krzysztof, „Przegląd kazań wygłoszonych w czasie koronacji obrazów i figur Matki Bożej w Polsce w II połowie XX wieku". Salvatoris Mater, t. 5, nr 2, 2003, ss. 247-316.

Staniek, Krzysztof. Teologia kazań wygłoszonych w czasie koronacji obrazów i figur Matki Bożej $w$ Polsce w II połowie XX wieku. 2003. Praca doktorska, Archiwum KUL.

Szymak, Grzegorz J. Prerogatywa zakonu Kaznodzieyskiego Z Faworow task, y dobrodzieystw osobliwszych, sobie od swey Matki y Opiekunki, Nieba y ziemi Krolowey SS. Maryi Panny Dotąd świadczonych z kronik domowych Zebrana, Krotkim ich natraceniem dla uwielbienia teyże SS. Matki Światowi Sarmackiemu [...] Objawiona. Wilno, 1755.

Witkowska, Aleksandra. „Uroczyste koronacje wizerunków maryjnych na ziemiach polskich w latach 1717-2005". Maria Regina. Koronacje wizerunków maryjnych w II Rzeczypospolitej, red. Aleksandra Witkowska, Wydawnictwo Biblos, 2011, ss. 29-51.

Witkowska, Aleksandra, i Joanna Nastalska-Wiśnicka. Ku ozdobie i obronie Rzeczypospolitej. Maryjne miejsca święte w drukach staropolskich. Wydawnictwo Werset, 2013.

Woziński, Andrzej. „Pruskie echa koncepcji artystycznych Mikołaja z Lejdy”. Porta Aurea 2018, ss. $5-42$.

Wyszyński, Stefan. Głos z Jasnej Góry. Wyd. 2. Akademia Teologii Katolickiej, 1986.

Wyszyński, Stefan. „Maryja - ukształtowana przez Trójcę Świętą - wzorem dla nas. Koronacja Matki Bożej Sejneńskiej. [Sejny, 7 września 1975]”. Instytut Prymasowski, wyszynski prymas.pl/wp-content/uploads/2020/10/1975-09-07-sejny.pdf. Dostęp 10.05.2021.

Wyszyński, Stefan. Wszystko postawiłem na Maryję. Wyd. 3 poprawione. Soli Deo/Éditions du Dialogue, 2007.

Wyszyński, Stefan. Zapiski więzienne. Wyd. 6 poprawione i uzupełnione. Soli Deo, 2006.

Wyszyński, Stefan. „Znak wierności Trójcy Świętej. Przed Mszą Świętą. [Sejny, 8 lipca 1979]”. Instytut Prymasowski, wyszynskiprymas.pl/wp-content/uploads/2020/10/1979-07-08-sejnyrocznica-koronacji.pdf. Dostęp 8.05.2021. 


\section{„TEOLOGIA PRZEPIĘKNEJ I ŁASKAMI SŁYNĄCEJ STATUY MATKI NAJŚWIĘTSZEJ SEJNEŃSKIEJ". DZIEŁO SZTUKI JAKO OBIEKT KULTU I DUSZPASTERSKIE WYZWANIE}

Streszczenie

Jedną z wielu spektakularnych inicjatyw duszpasterskich Prymasa Stefana Wyszyńskiego były koronacje papieskimi koronami kultowych wizerunków maryjnych. Przeprowadził ich czterdzieści siedem. Jedną z ostatnich była koronacja rzeźby Matki Bożej Sejneńskiej. Artykuł jest poświęcony analizie kazania koronacyjnego wygłoszonego 7 września 1975 r. w Sejnach. Ukoronowana figura należy do typu ikonograficznego tzw. Madonn szafkowych, do grupy rzeźb pomorskich, których powstanie łączono z zakonem krzyżackim; jej pierwotne pochodzenie i dzieje nie są znane. W 1602 r., wraz z fundacją klasztoru dominikanów, pojawiła się w Sejnach i bardzo szybko została otoczona kultem. Kult ten przetrwał kasatę klasztoru i jest żywy do dziś. Kontrowersyjna ikonografia Maryi z Dzieciątkiem - rzeźba skrywająca w swoim wnętrzu Trójcę Świętą (Tron Łaski) - stanowiła wyzwanie dla opiekunów sanktuarium. W XVII-XIX wieku obserwujemy proces powolnego wycofywania rzeczywistego wizerunku rzeźby i tworzenia jego kreacji na potrzeby kultu, poczynając od okrycia jej metalową sukienką aż do zakazu otwierania figury włącznie.

Kazanie koronacyjne ma wydźwięk trynitarny i w całości służy przekazaniu wiernym prawdy o działaniu Trójcy Świętej w życiu Kościoła oraz Jej szczególnej relacji z Maryją. W konkluzji Prymas Wyszyński nadał kultowej figurze nowe miano: Maryja od Trójcy Świętej. Tym samym dokonał rewitalizacji średniowiecznej ikonografii, wykorzystując nie tylko jej pierwotną wymowę ideową, ale także wpisując ją w aktualną posoborową mariologię trynitarną, zawartą w Konstytucji o Kościele Lumen gentium, a także w Adhortacji apostolskiej Pawła VI Marialis cultus. Jest to jedyne kazanie koronacyjne Prymasa Wyszyńskiego w całości inspirowane ikonografią koronowanego wizerunku kultowego.

Słowa kluczowe: Stefan Wyszyński; Sejny; Madonna szafkowa; ikonografia maryjna; Tron Łaski; Trójca Święta.

\section{"THE THEOLOGY OF THE BEAUTIFUL AND GRACIOUS STATUE OF THE MOST BLESSED MOTHER OF SEJNY": A WORK OF ART AS AN OBJECT OF WORSHIP AND A PASTORAL CHALLENGE}

\section{S u m m a r y}

One of the many spectacular pastoral initiatives of Primate Stefan Wyszyński was the coronation of cult Marian images with papal crowns. He did forty-seven of them, one of the last was the coronation of the statue of Our Lady of Sejny (Sejny is a town in north-eastern Poland). The article analyses the coronation sermon delivered on this occasion on September 7, 1975 in Sejny.

The crowned figure belongs to the iconographic type of the so-called Shrine Madonnas, or the group of Pomeranian sculptures, the creation of which was linked to the Teutonic Order. Its origin and history are unknown. In 1602, together with the foundation of the Dominican monastery, it appeared in Sejny and very quickly became worshiped. This cult survived the dissolution of the monastery and is still alive today. The controversial iconography of Mary with the Child a sculpture housing the Holy Trinity (Throne of Grace) - was a challenge for the guardians of the 
sanctuary. From the 17th to 19th centuries, we observe the slow withdrawing of the actual image of a sculpture and making its likeness for the purposes of worship: from covering the figure with a metal robe to prohibiting a ban on the opening of the statue.

The coronation sermon bears Trinitarian overtones and is entirely intended to convey to the faithful the truth about the operation of the Holy Trinity in the life of the Church and Its special relationship with Mary. In his conclusion, Primate Wyszyński gave the cult figure a new name: Mary of the Holy Trinity. Thus, he revitalized the medieval iconography, using not only its original ideological significance, but also inscribing it in the current post-conciliar Trinitarian Mariology, contained in the Constitution on the Church Lumen Gentium, as well as in the Apostolic Exhortation by Paul VI Marialis Cultus. It is the only coronation sermon delivered by Primate Wyszyński inspired entirely by the iconography of the crowned cult image.

Translated by Stanistaw Sarek Proofread by Tomasz Pałkowski

Keywords: Stefan Wyszyński; Sejny; Shrine Madonna; Marian iconography; Throne of Grace; Holy Trinity. 


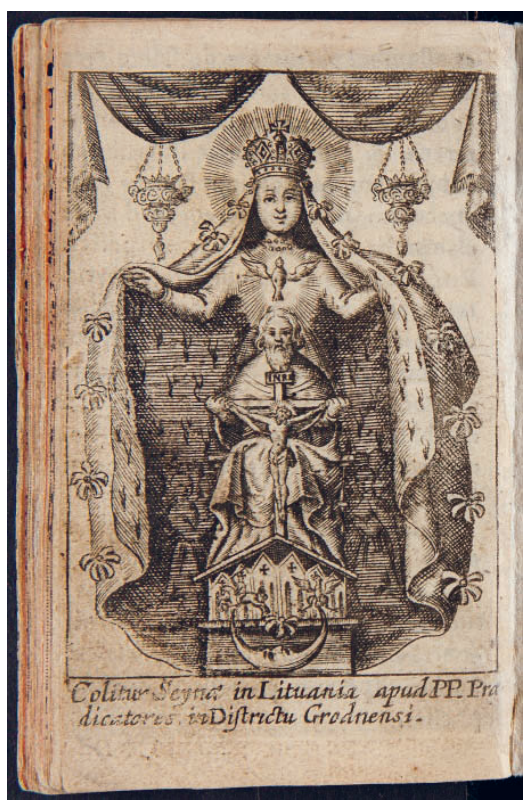

1. Matka Boża Sejneńska, rycina z J. Drews, Methodus peregrinationis..., Vilnae, 1684. Vilniaus universiteto biblioteka, kolekcijos.biblioteka.vu.lt/en/islandora/ object/kolekcijos\%3AVUB01_000240392\#00060

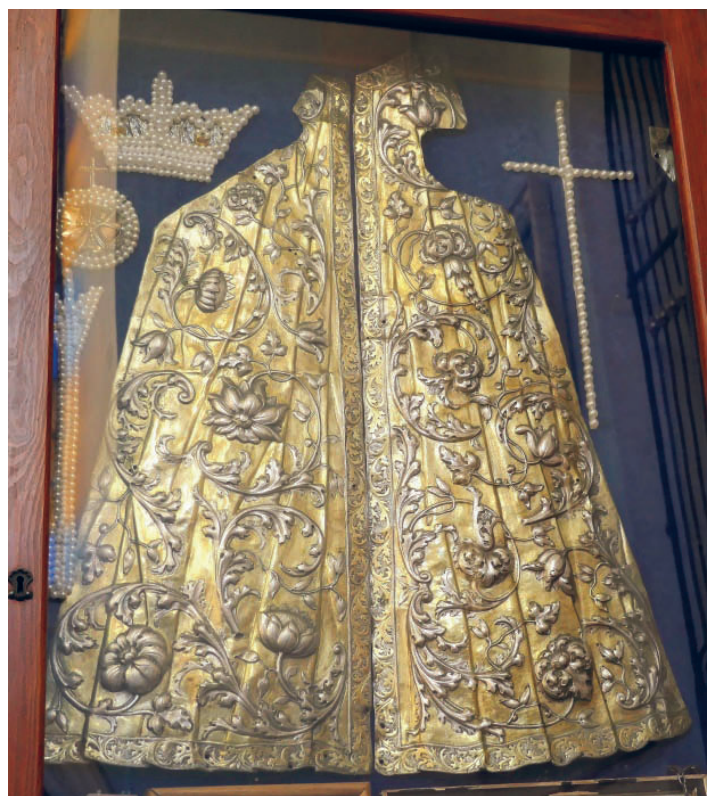

2. Srebrna sukienka na figurę Matki Bożej Sejneńskiej, 1720 r., współczesna ekspozycja w kaplicy bpa Piotra Wierzbowskiego. Fot. Aneta Kramiszewska 


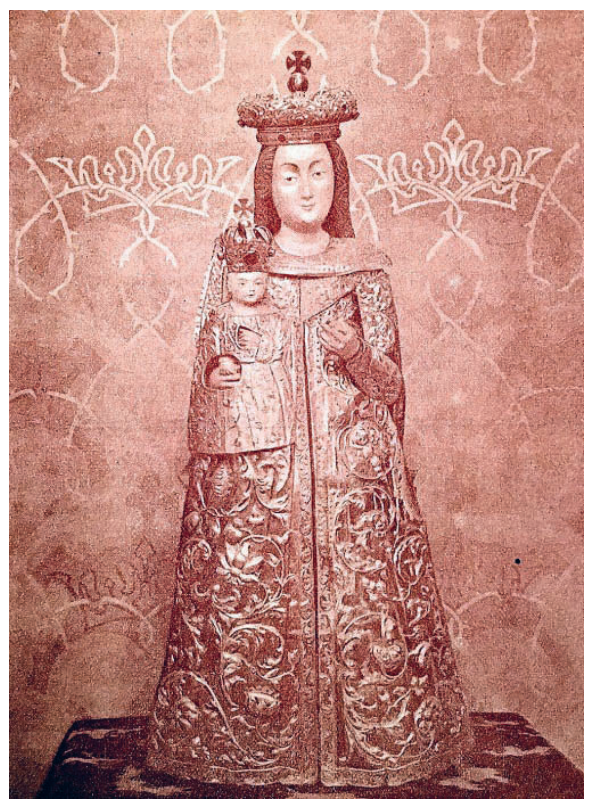

3. Matka Boża Sejneńska, widok figury w metalowej sukience, fotografia archiwalna sprzed $1939 \mathrm{r}$.

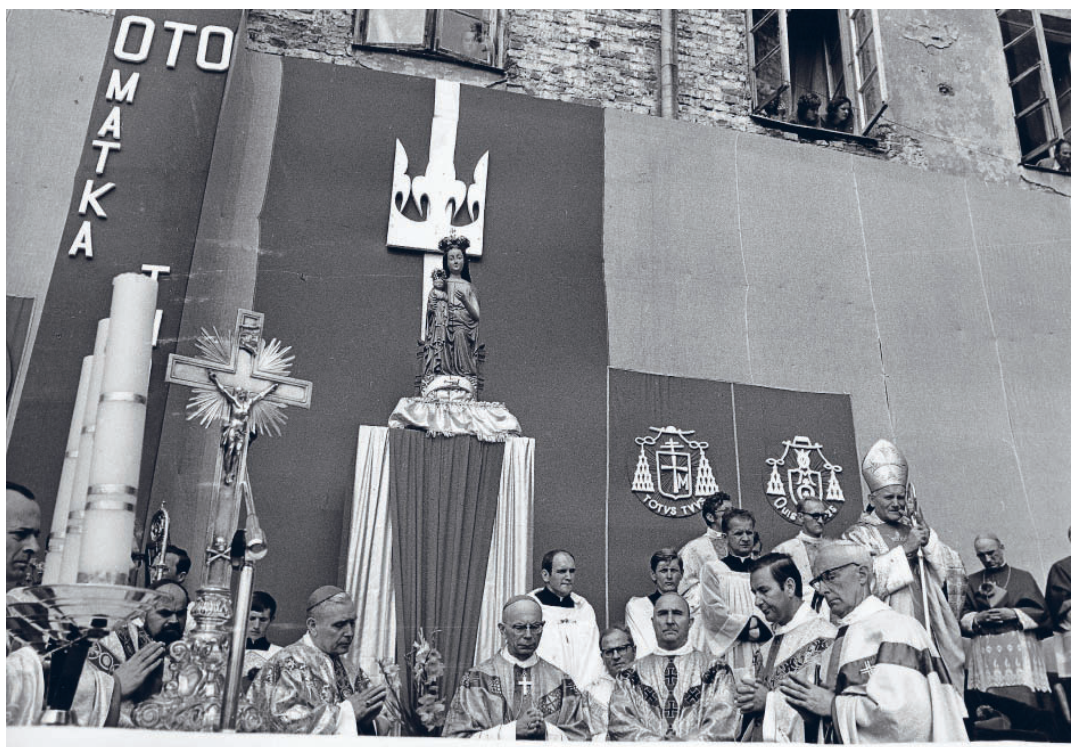

4. Uroczystości koronacyjne, Sejny, 7 września 1975 r. Fot. Jan Lupo 


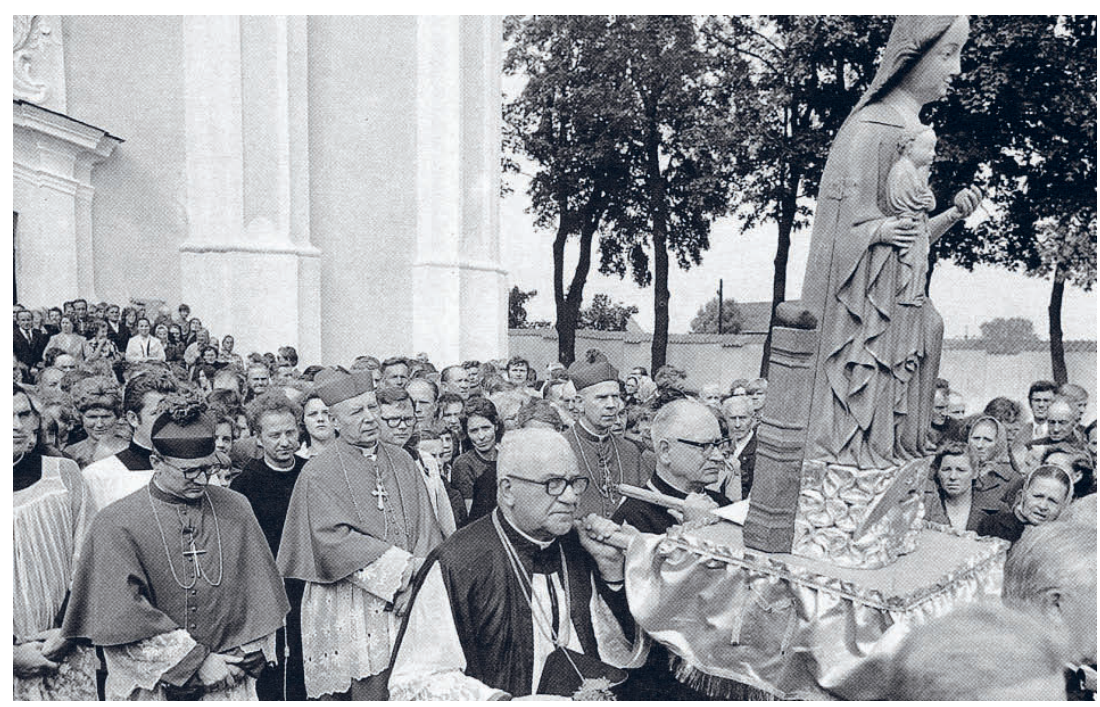

5. Uroczystości koronacyjne, Sejny, 7 września 1975 r. Fot. Jan Lupo

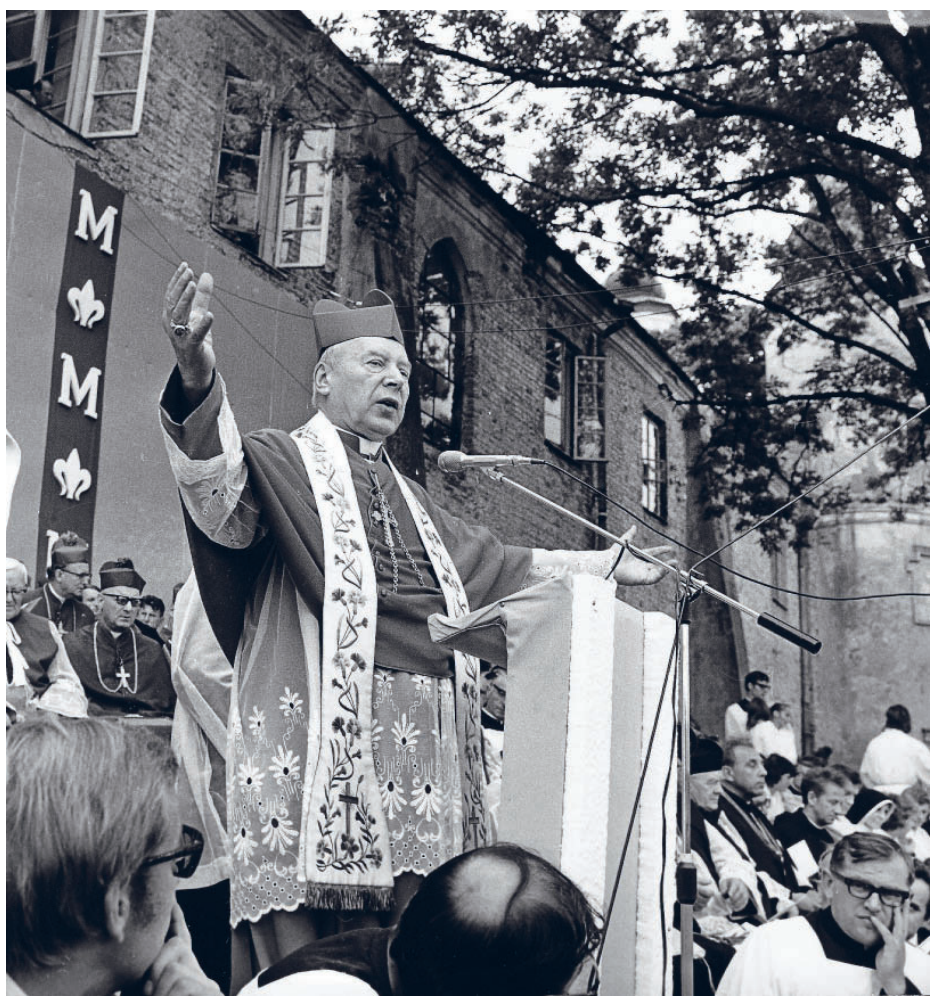

6. Ksiądz Prymas Stefan Wyszyński przemawiający do wiernych w trakcie uroczystości koronacji wizerunku Matki Bożej Sejneńskiej, Sejny, 7 września 1975 r. Fot. Jan Lupo 
82

ANETA KRAMISZEWSKA

Dropiem M. Puartowi dtamirians Ropenthy

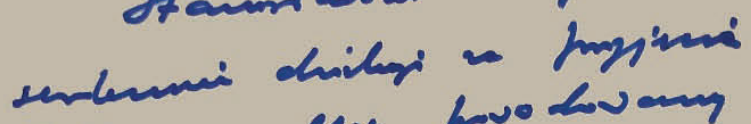

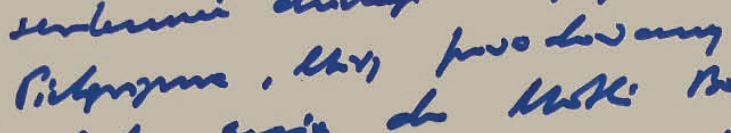
ossmote cuare de laste Buj.

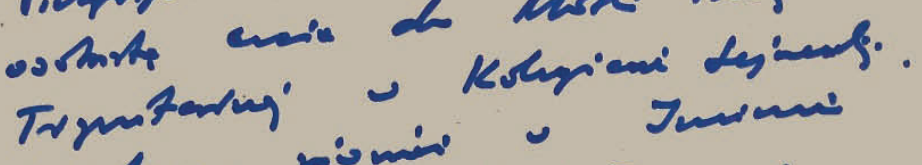

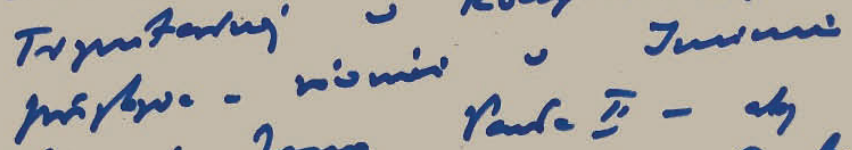
gie s. Pom rane E - dy

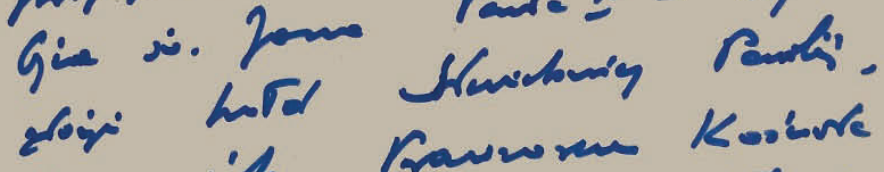
chro ith Fawnom Koowre. Triy si. - $\therefore$ osinicederi, a -cestr Fipur lete Bris.

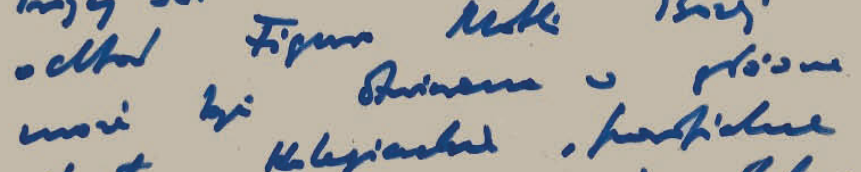

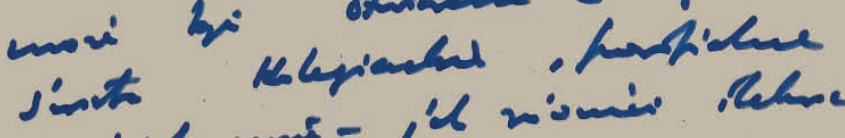

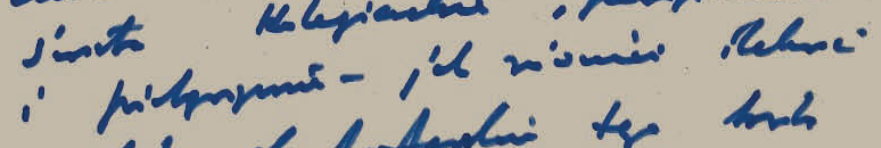

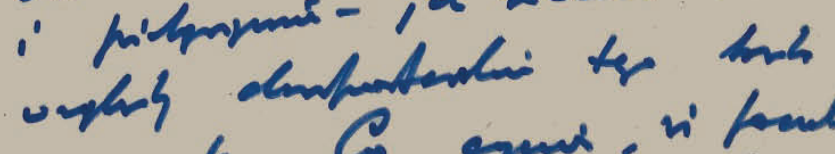

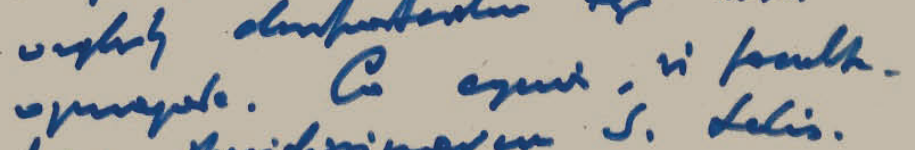
trom spicidssimerem s. Lelis.

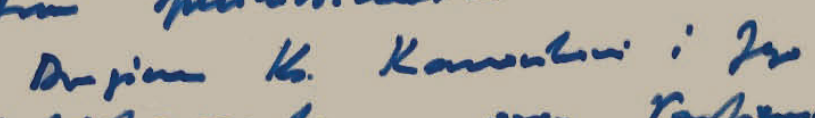

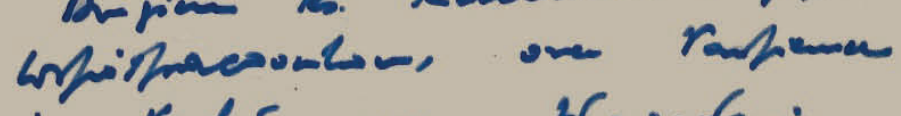
: richŕnow broprami

+ deper Kanl Vyaple. Sing, 28.7.1928

7. Karta księgi pamiątkowej z wpisem Prymasa Stefana Wyszyńskiego, dokonanym 28 lipca 1979 r. Fot. Archiwum Parafii pw. Nawiedzenia Najświętszej Maryi Panny w Sejnach 


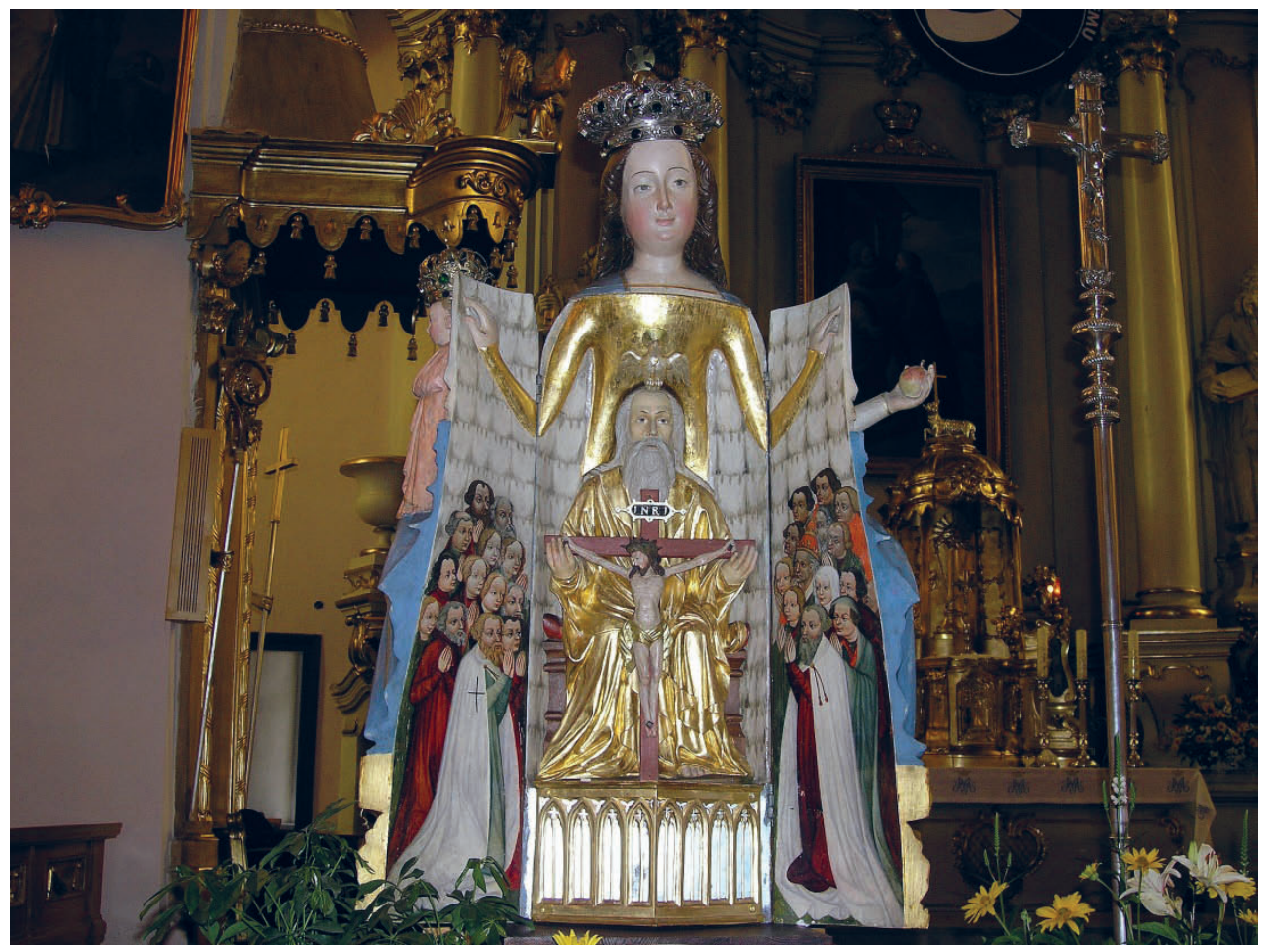

8. Otwarta figura Matki Bożej od Trójcy Świętej, eksponowana przed ołtarzem głównym w rocznicę koronacji wizerunku. Fot. Maria Ołdakowska 